\title{
Primer peritonitis egészséges serdülő fiúban
}

\author{
Farkas László dr. ${ }^{1}$ - Lazáry György dr. ${ }^{1}$ - Köves Ilona dr. ${ }^{2}$ \\ Csákváry Violetta dr. ${ }^{2}$ - Rónaky Rebeka dr. ${ }^{1}$. Nagy Tamás dr. ${ }^{3}$ \\ ${ }^{1}$ Markusovszky Egyetemi Oktatókórház, Csecsemő- és Gyermekgyógyászati Osztály, \\ Gyermeksebészeti Szakambulancia, Szombathely \\ ${ }^{2}$ Markusovszky Egyetemi Oktatókórház, Csecsemő- és Gyermekgyógyászati Osztály, Szombathely \\ ${ }^{3}$ Markusovszky Egyetemi Oktatókórház, Központi Radiológiai Osztály, Szombathely
}

\begin{abstract}
Az egészséges, hajlamosító tényező nélküli gyermekeknél a primer peritonitis rendkívül ritka. A klinikai kép egyértelmú hajlamosító tényezők és tünetek hiányában nem különbözik a szekunder peritonitisektől. Emiatt a diagnózis szinte mindig intraoperatív. Esetismertetés: 15 éves, korábban egészséges fiút kezeltünk enteritisnek megfelelő panaszokkal. A panaszok kezdetétól 24 órán belül akut has és szeptikus sokkos állapot alakult ki. A has komputertomográfos vizsgálatakor apró levegőzárványok látszottak a has középvonalában és a terminalis ileum mellett. Sürgôsséggel laparotomiát végeztünk perforációs peritonitis gyanúja miatt. A mútét során azonban a purulens peritonitis hátterében perforációt nem találtunk. Széles spektrumú empirikus, majd célzott antibiotikumkúrát alkalmaztunk. A szeptikus sokkot és szövődményeit sikeresen kezeltük. A primer peritonitis forrását nem tudtuk azonosítani. A gyermek a hazabocsátása óta panaszmentes. Primer peritonitisnél a nem specifikus, rapidan progrediáló tünetek miatt a sürgős mútét általában elkerülhetetlen. Megfelelő antibiotikum- és szupportív terápiával a prognózis kedvező.
\end{abstract}

Orv Hetil. 2020; 161(23): 977-979.

Kulcsszavak: primer peritonitis, akut has, intraoperatív diagnózis

\section{Primary peritonitis in an adolescent boy}

Primary peritonitis is very rare in healthy children without predisposing factors. In the absence of unique factors and signs, the clinical picture does not differ from secondary peritonitis. Therefore, the diagnosis is almost always an intraoperative diagnosis. Case report: We admitted a previously healthy 15 -year-old boy with symptoms of acute enteritis. Within 24 hours, he developed acute abdomen and signs of septic shock. Computer tomography of the abdomen revealed air bubbles in the middle of the abdomen and near the terminal ileum. Suspecting perforation, we performed an emergency laparotomy. However, there was no perforation to be found in the background of the purulent peritonitis. We initiated empirical broad-spectrum antimicrobial therapy which we later adjusted. Septic shock and complications were treated successfully. We could not find the source of the primary peritonitis. Since hospital discharge, the child has been asymptomatic. In primary peritonitis, due to the nonspecific, rapidly progressing symptoms, an emergency surgery can not be avoided. With proper antibiotics and supportive therapy, the prognosis is favourable.

Keywords: primary peritonitis, acute abdomen, intraoperative diagnosis

Farkas L, Lazáry Gy, Köves I, Csákváry V, Rónaky R, Nagy T. [Primary peritonitis in an adolescent boy]. Orv Hetil. 2020; 161(23): 977-979.

(Beérkezett: 2020. február 12.; elfogadva: 2020. február 17.)

\section{Rövidítések}

$\mathrm{BMI}=($ body mass index $)$ testtömegindex; CRP = C-reaktív protein; $\mathrm{CT}=$ (computed tomography) számítógépes tomográfia; INR = (international normalized ratio $)$ nemzetközileg normalizált ráta
Szekunder peritonitis esetén a kórokozók valamelyik hasüregi szerv perforációja, károsodása miatt jutnak a hasüregbe [1]. Primer peritonitisnél baktériumok haematogen, lymphogen úton, direkt inokulációval, a bélfa- 
lon átmigrálva vagy a genitáliákból aszcendálva okoznak hashártyalobot [1].

A primer peritonitis az akut hasi kórképeknek csupán 1-2\%-a [2]; 4-9 éves korban a leggyakoribb [3]. Kialakulására az immundeficientiát okozó kórképek (föként a krónikus májelégtelenség, a nephrosisszindróma, az immunhiányos állapotok, a ventriculoperitonealis shunt, a peritonealis dialízis, a malignus betegségek, az autoimmun betegségek) és a női nem hajlamosítanak [4]. Egészséges, hajlamosító tényező nélküli fiúknál rendkívül ritka.

A klinikai megjelenés - egyértelmű hajlamosító tényezők és ráutaló tünetek hiányában - nem specifikus [4]. Hasfájás, láz, hányás, hasmenés jelentkezik kezdetben [3]. A panaszok kezdetétól 24 órán belül szepszis, majd szeptikus sokkos állapot alakulhat ki [5]. A képalkotó vizsgálatok eredményétől függetlenül az általános állapot és a hasi status romlása (diffúz izomvédekezés, ileusos tünetek) miatt akut sebészeti beavatkozás szükséges. Az exploráció során a hashártyagyulladásnak nincs intraabdominalis forrása. A diagnózis az esetek döntő többségében intraoperatív.

A hasưri folyadék mikrobiológiai vizsgálata az esetek 90\%-ában monobakteriális infekciót igazol. Escherichia coli, Streptococcus pneumoniae, Klebsiella pneumoniae, Staphylococcus aureus a leggyakoribbak. Serdülö- és felnöttkorban az E. coli és a Klebsiella, gyermekkorban a Streptococcus és a Staphylococcus okozta fertőzések dominálnak. Az anaerob kórokozók (Bacteroides, Clostridium) gyakorisága csupán 1\% [2].

A kezelés alapja a parenteralis széles spektrumú, majd a mikrobiológiai vizsgálatok eredményének megfelelő célzott parenteralis antibiotikumterápia. A szeptikus sokkos állapot és az alapbetegség adekvát ellátása is kiemelten fontos.

\section{Esetismertetés}

Betegünk anamnézisében 1 éves korban dongaláb miatt végzett mütét szerepel. A 15 éves fiút 3 órája tartó görcsös hasfájás, hányás és hőemelkedés miatt utalták osztályunkra. A környezetében elmondás szerint hasonló panasz nem volt.

A jó általános állapotú, normál tápláltságú (BMI 23 $\mathrm{kg} / \mathrm{m}^{2}$ ) gyermek felvételi statusából a mély betapintás során jelentkező enyhe diffúz hasi nyomásérzékenység emelhető ki. A laborvizsgálatok során a minőségi vérkép balra tolt (neutrophil 75\%, lymphocyta 24\%), a CRP ( $2 \mathrm{mg} / \mathrm{l})$, a fehérvérsejtszám $(9 \mathrm{G} / \mathrm{l})$, a máj- és vesefunkciós paraméterek, valamint a vizelet általános laborvizsgálatának értékei a normáltartományban voltak. Parenteralis folyadékpótlást és nulldiétát alkalmaztunk.

Tíz órával a felvételt követően profúz savhematinos hányás, láz és hasmenés jelentkezett. A hasi panaszok fokozódtak. A felső intestinalis vérzés gyanúja miatt végzett gasztroduodenoszkópia nem igazolt vérzésforrást, perforációt. A natív hasi felvételen csak kissé lekerekített bal oldali sinus, a hasi ultrahangvizsgálat során $1 \mathrm{~cm}$ legnagyobb vastagságú szabad hasi folyadék látszott. A CRP normális fehérvérsejtszám mellett emelkedett (75 mg/l).

24 órával a panaszok kezdete után defanse és szeptikus sokkos állapot alakult ki. A CRP $240 \mathrm{mg} / 1$, a prokalcitonin $200 \mathrm{ng} / \mathrm{l}$ felett, a fehérvérsejtszám 3,8 G/1, az INR 1,8 , a protrombin $41 \%$ volt. A hemokultúra levétele után pentaglobint és parenteralis kombinált antibiotikumkúrát (meropenem, vankomicin, metronidazol) indítottunk ex juvantibus. A sokkos állapot miatt folyadékresuscitatiót, keringéstámogatást (arterenol) és arcmaszkon keresztüli oxigénterápiát, a haemostasis zavara miatt friss fagyasztott plazmát alkalmaztunk.

A hasi CT-vizsgálat során nagy mennyiségű hasi és mellkasi folyadékot, valamint apró levegőzárványokat írtak le a has középvonalában és a terminalis ileum mellett (1. és 2. ábra). Perforációs peritonitis gyanúja miatt laparotomiát végeztünk. A medián laparotomia során diffúz, purulens peritonitist találtunk. Az appendix, az epehó-

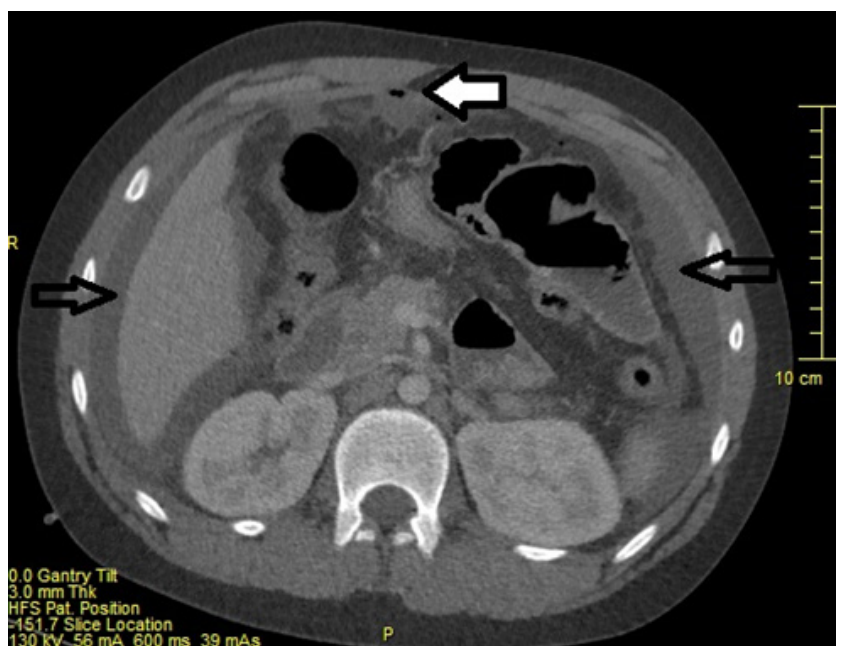

l. ábra $\quad$ Axiális síkú metszet a hasról. A májszél körül és a has bal oldalán szabad hasi folyadék ábrázolódik (fekete kontúrú nyilak), ventralisan a folyadékon belül apró szabad levegőzárványok láthatók (fehér nyíl)

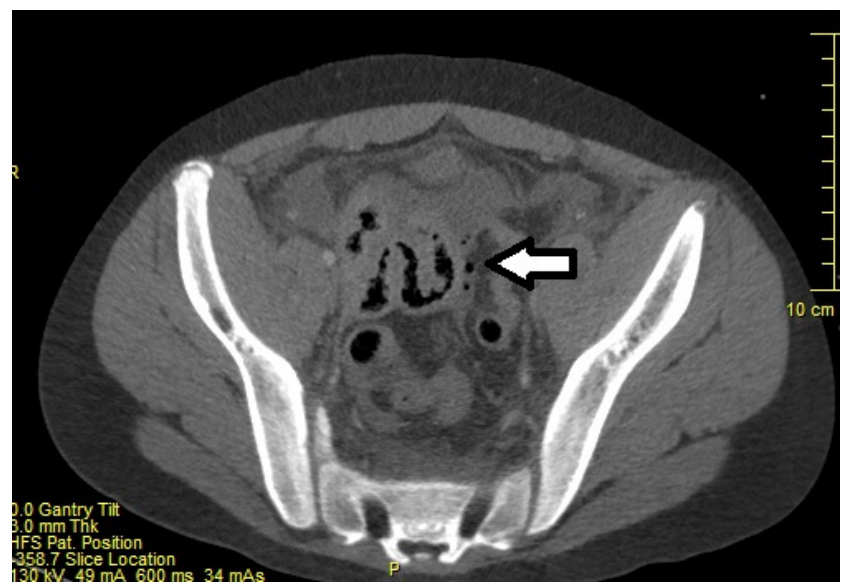

2. ábra

Axiális síkú metszet a kismedencei régióról. A belek mentén apró szabad levegőzárványok ábrázolódnak (fehér nyíl) 
lyag és a típusos helyen lévő Meckel-diverticulum ép volt. A vastag- és vékonybeleket alaposan átvizsgálva, a bursát megnyitva a gyomrot betadinoldattal feltöltve és áttapintva sem találtunk perforációt. A hasưri folyadékból mikrobiológiai vizsgálatra (aerob, anaerob) mintát vettük. Hasi drén behelyezése után a hasfalat zártuk. A betegséget akut sebészi kezelést igénylő hasi kórkép hiányában primer peritonitisnek tekintettük.

A gyermek a mútét után egy napig igényelt keringéstámogatást. A hasi panaszok néhány nap alatt fokozatosan megszû́ntek. Az első posztoperatív héten a primer peritonitis és a szeptikus sokk szövődményeként pancreatitis és intrahepaticus cholestasis alakult ki, mely nulldiéta és parenteralis táplálás mellett rövid idő alatt gyógyult. A gyermek táplálását fokozatosan felépítettük.

A hasưri folyadékból E. coli és Bacteroides fragilis tenyészett ki. A megkezdett antibiotikumterápiát érzékenység alapján metronidazol + vankomicin kombinációra módosítottuk. A gyulladásos paraméterek kezdetben regrediáltak, majd a 14. posztoperatív naptól ismét emelkedtek. Elhúzódó láz valamint permanens gyulladásos és katabolikus állapot alakult ki. Az intenzív parenteralis, majd enteralis táplálás ellenére jelentős fogyás jelentkezett (a BMI $18 \mathrm{~kg} / \mathrm{m}^{2}$-re csökkent).

A hemokultúrákból, a hasi drén, centrális vénás kanül és hólyagkatéter leoltásából kórokozó nem tenyészett ki. Hasi ultrahang-, majd CT-vizsgálattal a hasi és a retroperitonealis tályogot kizártuk. A mellkasi CT-vizsgálat a hátsó sinusban bal oldalon $4 \mathrm{~cm}$, jobb oldalon $3 \mathrm{~cm}$ legnagyobb vastagságú letokolt folyadékot írt le. A folyadékgyülem konzervatív kezelése és az antibiotikumterápia módosítása mellett döntöttünk. Ampicillin-, tobramicin-, metronidazolkúrát indítottunk. A lázas állapot megszúnt, a letokolt folyadék felszívódott. A gyermeket gyógyult állapotban, emelkedő súlygörbével otthonába bocsátottuk, részletes kivizsgálása során sem találtunk a primer peritonitis kialakulására hajlamosító betegséget. Az eddigi - közel egyéves - követése alatt mindvégig tünet- és panaszmentes volt.

\section{Megbeszélés}

A korábban egészséges serdülő nagyfiúnál a panaszok kezdetétől egy napon belül defanse és szeptikus sokkos állapot alakult ki. A hasi CT-vizsgálat is felvetette a perforáció lehetőségét, melyet a laparotomia során kizártunk. A hasi CT-n a perforáció gyanúját felvető levegözárványokat a hasűri folyadékból kitenyészett obligát anaerob Bacteroides gáztermelése okozhatta. A peritonitis és a szeptikus állapot miatt akutan nem távolítottuk el az ép appendixet és Meckel-diverticulumot. A posztope- ratív szakban kialakult pancreatitist, intrahepaticus cholestasist, az elhúzódó gyulladásos és katabolikus állapotot a szeptikus sokk szövődményének tartjuk [6-8].

$\mathrm{Az}$ akut hasi tünetek hátterében a primer peritonitis az egészséges, hajlamosító tényező nélküli gyermekeknél ritka. Az etiológia gyakran rejtve marad. Az atípusos klinikum miatt a diagnózis megbízható preoperatív felállítása szinte lehetetlen. Az akut hasi tünetek és a beteg állapotának gyors romlása miatt sürgős mütét szükséges. A hasüregi szervek alapos átvizsgálása során nincs akut sebészeti megoldást igénylő elváltozás. A kezelés alapja a parenteralis széles spektrumú, majd lehetőség szerint a célzott antibiotikumterápia és a megfelelő szupportív ellátás.

Anyagi támogatás: A közlemény megírása anyagi támogatásban nem részesült.

Szerzői munkamegosztás: F. L.: A beteg kezelése, a kézirat megírása. L. Gy., K. I.: A beteg kezelése, a szöveg korrektúrája. N. T.: A képalkotó vizsgálatok elvégzése és prezentálása. Cs. V., R. R.: A kézirat szakmai véleményezése. A cikk végleges változatát valamennyi szerző elolvasta és jóváhagyta.

Érdekeltségek: A szerzőknek nincsenek érdekeltségeik.

\section{Irodalom}

[1] Kelemen E. Peritonitis. In: Acute abdominal diseases and their physical examination. [Hashártyagyulladás. In: Akut hasi kórképek és fizikális kórismézésük.] Medicina Könyvkiadó, Budapest, 1993; pp. 60-71. [Hungarian]

[2] Khilji MF. Primary peritonitis - a forgotten entity. European J Pediatr Surg Rep. 2015; 3: 27-29.

[3] Navia MJ, Caroli PL. Primary peritonitis in previously healthy children. [Peritonitis primaria en niños sanos.] An Pediatr (Barc). 2004; 61: 554-557. [Spanish]

[4] Soto VV, Miranda VR, Arjona EL, et al. Peritonitis in children. [Peritonitis en el niño.] Medisur. 2005; 3: 87-91. [Spanish]

[5] Carmo L, Amarall M, Bonetet B, et al. Primary peritonitis in a healthy boy - case report. Acad J Ped Neonatol. 2017; 4: 55-56.

[6] Iskander KN, Osuchowski MF, Stearns-Kurosawa DJ, et al. Sepsis: multiple abnormalities, heterogeneous responses, and evolving understanding. Physiol Rev. 2013; 93: 1247-1288.

[7] Nesseler N, Launey Y, Aninat C, et al. Clinical review: the liver in sepsis. Crit Care 2012; 16: 235.

[8] Chaari A, Hakim KA, Bousselmi K, et al. Pancreatic injury in patients with septic shock: a literature review. World J Gastrointest Oncol. 2016; 8: 526-531.

(Farkas László dr., Szombathely, Markusovszky út 5., 9700 e-mail: farkaslaszlo60@freemail.hu)

A cikk a Creative Commons Attribution 4.0 International License (https://creativecommons.org/licenses/by/4.0/) feltételei szerint publikált Open Access közlemény, melynek szellemében a cikk bármilyen médiumban szabadon felhasználható, megosztható és újraközölhető, feltéve, hogy az eredeti szerző és a közlés helye illetve a CC License linkje és az esetlegesen végrehajtott módosítások feltüntetésre kerülnek. (SID_1) 